\title{
Content Verification in Social Media
}

\author{
Vyacheslav Ryabichev \\ Institute of Journalism, Taras Shevchenko National University of Kyiv, \\ 36/1 Melnikova str., Kyiv, 04119, Ukraine \\ Corresponding author's e-mail address: ryabichev@gmail.com
}

\begin{abstract}
The main objectives of the study are: elaboration of the operative algorithm for professional online journalists under information warfare (IW) conditions; analysis of the modern methods and tools for the effective verification of information; application of the decision support systems (DSS) for the content distribution in social media; specification of the set of rules for network reporters to itemize their activity.

In this study the issue of verifying the information received from the World Wide Web is analysed, in particular, the information spread during the military aggression of the Russian Federation against Ukraine in 2014-2015. We also present and justify some modern means of counteracting the spread of intentionally distorted information and hostile propaganda. We focus on using content analysis, comparative analysis, full-text searching, pattern recognition, and opensource intelligence (OSINT) method.

Through using specific facts and findings we analyse the features of the work of an online journalist during the warfare and modern digital tools for content search, verification, comparison and analysis.

The results and conclusions of this investigation allow generalizing and structuring some methods and techniques of content verification. A number of rules and helpful hints for enhancing the efficiency of online journalists are proposed. Current trends in development of social media allow predicting further increase of the Internet audience and consequently an increasing amount of information on the web. With the development of citizen journalism (street journalism) in Ukraine, the significance level of journalistic responsibility for information dissemination in mass media has been constantly increasing. Out of a huge amount of reports and data, a journalist must be able to identify the most accurate and up-to-date ones, check them promptly, and distribute on cross-media platforms. Under such conditions, an online reporter is obliged to possess modern skills of dealing with digital tools for content verification, and to keep in contact with experts whom he can ask for advice.
\end{abstract}

KEYWORDS: verification, social media, social networks, cross-media, Internet journalism, citizen journalism, monitoring, information war, crowdsourcing. 
УДК $366.652: 316.77$

\section{Верифікація контенту в соціальних медіа}

Рябічев Вячеслав Львович, Інститут журналістики Київського наџіонального університету імені Тараса Шевченка, дочент, кандидат фізико-математичних наук.

\section{Резюме}

Розглянуто питання перевірки інформації, отриманої з Всесвітньої павутини, в тому числі в умовах інформаційної агресії з боку Російської Федерації протягом 2014-2015 років.

Метою дослідження було розробити та обгрунтувати сучасні методи протидії поширенню спотвореної інформації та ворожої пропаганди за допомогою методів контент-аналізу, порівняльного аналізу, повнотекстових пошуків, розпізнавання образів, OSINT-методу (розвідка за відкритими джерелами).

На конкретних фактах проаналізовано особливості роботи онлайн-журналіста під час воєнних дій та сучасні цифрові інструменти для пошуку, перевірки, порівняння та аналізу різноманітного контенту.

Створено набір правил та запропоновано нові методики для роботи репортера соціальних медіа в умовах інформаційної війни.

Ключові слова: верифікація, соціальні медіа, соціальні мережі, крос-медіа, інтернетжурналістика, громадянська журналістика, моніторинг, інформаційна війна, краудсорсинг,

\section{Рябичев В.Л. Верификация контента в социальных медиа.}

Резюме. Рассмотрены вопросы проверки информации, полученной из Всемирной паутины, в том числе в условиях информационной агрессии со стороны Российской Федерации в течение 2014-2015 годов.

Целью исследования была разработка и обоснование современных методов противодействия распространению искаженной информации и вражеской пропаганды с помощью методов контент-анализа, сравнительного анализа, полнотекстовых поисков, распознавания образов, OSINT-метода (разведка по открытым источникам).

На конкретных фактах проанализированы особенности работы онлайн-журналиста во время военных действий и современные цифровые инструменты для поиска, проверки и анализа разнообразного контента.

Разработан набор правил и предложены новые методики для работы репортера социальных медиа в условиях информационной войны.

Ключевые слова: верификация, социальные медиа, социальные сети, крос-медиа, интернет-журналистика, гражданская журналистика, информационная война, краудсорсинг.

\section{1. Вступ}

Питання оперативної та надійної перевірки поширюваної інформації є однією $з$ найважливіших професійних рис журналіста, а особливо журналіста мережевих видань. Вперше спроби аналізу контенту, створеного інтернет-користувачами, були зроблені в роботах сера Тіма Бернерса Лі у 90-ті роки минулого століття. У своїх дослідженнях він 
розглядав модель семантичної мережі, алгоритм якої передбачав самовдосконалення за рахунок контенту, створеного відвідувачами веб-ресурсів. Згодом ці ідеї були реалізовані корпорацією Google в низці своїх програмних продуктів, насамперед при створенні пошукової системи. Пізніше, в 2003 році, американський видавець Тім О'Рейлі запропонував новий термін Web2.0 [1] для позначення нового етапу в розвитку Всесвітньої павутини, пов'язаного з виникненням соціальних медіа та бурхливим поширенням UGC-контенту та "вуличної" журналістики. Природно, що стрімке поширення великої кількості інформації мережевими каналами комунікації змусило новинарів витрачати більше часу на перевірку повідомлень. А це в свою чергу стало чинником виникнення цілої низки програмних продуктів, що повинні були допомогти онлайн-репортеру в перевірці інформації. Тому зараз, коли ми говоримо про професійного мережевого журналіста, обов'язково згадуємо вміння перевіряти контент, отриманий з соціальних медіа. У роботі [2] детально розглянуті необхідні навички сучасного мережевого онлайн-репортера, серед яких однією 3 найважливіших є верифікація інтернет-контенту.

Проблеми ретельної перевірки інформації в соціальних медіа станом на 2011-2013 роки розглянуті в роботах [3; 4; 5] британської журналістки Рейчел Бартлетт (Rachel Bartlett). Зокрема багато уваги було приділено перевірці контенту, який поширюється в мікроблозі Твіттер, та організації комунікації з онлайн-аудиторією. Відомий український дослідник Георгій Почепцов в одній зі своїх останніх робіт [6] системно розглянув історію виникнення і розвитку методології інформаційних воєн, проаналізував різницю між різними моделями створення штучних інформаційних хвиль. Зокрема в цій роботі велика увага приділяється соціальним медіа - середовищу, яке дуже швидко збільшує свою аудиторію. У більш вузькому розумінні проблема верифікації новин є однією зі складових питання ведення інформаційних війн [6].

Американські професори Джон Арквілла (John Arquilla) та Девід Ронфельдт (David Ronfeldt) у своїй книзі [7] від більш загального поняття - інформаційні війни - переходять до терміна «мережеві війни», розглядаючи протистояння людей у Всесвітній павутині. На думку цих авторів, нові технології, на кшталт Web2.0, способи мислення й дії зробили неймовірно потужним інтернет-простір і перетворили звичайне життя на дуже складне із погляду традиційних ієрархій. Одне з їхніх перших тверджень було пов'язане з визначенням військових стратегій у зв'язку з інформаційною революцією - те, що визначають терміном «кібервійни». Новий термін «мережева війна», на їхню думку, дає краще зрозуміти новий формат конфліктів та протистоянь, до якого підійшло людство. Небезпека мережевих війн у тому, що сьогодні людина може спрямовувати сили одразу в кількох напрямках 3 метою винищення або захоплення території. Комп'ютерні технології та соціальні медіа дають можливість, створюючи та поширюючи власний контент, керувати зброєю на відстані в кілька тисяч кілометрів, спрямовувати удар, корегувати свої дії та досягати результату лише за кілька секунд.

Арквілла і Ронфельдт вважають, що мережеві війни перетворюються на нову «Столітню війну» - чи не найважчу у світі за всю історію, бо нападника вперше не видно. Крейг Сільверман у своїх роботах [8; 9] перевірку контенту, отриманого з соціальних медіа, вважає одним з основних завдань інтернет-журналіста. У роботі [8] він пропонує покрокові інструкції щодо того, як під час надзвичайних ситуацій працювати 3 контентом, отриманим від читачів. У кризових ситуаціях соціальні мережі перевантажені оновленнями інформації щодо стану ситуації, запитами про допомогу, звітами про розвиток подій і рятувальною інформацією. Повідомлення коректної інформації часто є критичним для точного спрямування допомоги від громадян та рятівників. У посібнику розглянуті практичні поради щодо того, яким чином перевіряти та використовувати інформацію, отриману від широкого кола інтернет-дописувачів, а також дієві рекомендації щодо організації підготовки ньюзрумів. Поради автора насамперед призначені для професійних онлайн- 
журналістів, але є цінними також для громадських репортерів, волонтерів, студентівжурналістів, науковців, що досліджують соціальні медіа.

В іншій своїй роботі [9], яка написана в співавторстві з американським журналістом та публічним діячем Джеффом Ярвісом, Сільверман розглядає проблему спростування помилково поширеної в Мережі інформації, радить, як донести виправлену та уточнену інформацію до тієї самої мережевої аудиторії. У [9] розглянуті найбільш типові помилки онлайн-репортерів, проведена їх класифікація, проаналізовані причини цих помилок та розроблені поради, як оперативно їх спростувати та мінімізувати негативний вплив на аудиторію. У книзі наведено багато життєвих прикладів, які описують проблеми поширення інформації в північноамериканських соціальних медіа. Низка 3 них є також типовими для України.

Поль Бредшоу (Paul Bradshaw), британський інтернет-журналіст та блогер, професор Лондонської школи журналістики, у своїх дописах у Твіттері [10] детально аналізує небезпеку поквапливого поширення неперевіреної інформації та закликає бути обережним, незалежно від ступеня «вибуховості» контенту. У своїй книзі [11] він аналізує, як можна зібрати факти з сотень джерел, перевірити й обробити їх та оперативно подати в новини. Британський журналіст Associated Press Фергус Белл (Fergus Bell) у своїх дописах в Твіттері [12] аналізує небезпеку поширення неперевіреної інформації з соціальних медіа та застерігає від цього. У своєму виступі на шведському радіо Sverige Radio 29 травня 2013 року [13] він розглядає питання, як професійно працювати онлайн-репортеру з контентом, що згенерований читачами того чи іншого медіа (UGC). Він зазначає, що 100 годин відео завантажуються на YouTube кожну хвилину, 400 млн. твітів розміщуються щодня. Всі ці дописувачі, спілкуючись у соціальних медіа, створюють новини. На думку Белла, за рахунок цього контенту можна наповнювати стрічку новин протягом цілого дня. Величезна кількість інформації доступна на різних платформах і в різних форматах. Але журналіст повинен вміти використати цей нескінченний контент, уважно відокремити факти від вигадки і знайти точні дані, які можна буде оприлюднити. Агенція Associated Press, де він працює, встановила суворі стандарти перевірки UGC-контенту, кожне повідомлення проходить багаторазову перевірку. Це забирає час, але збільшує довіру аудиторії до онлайнмедіа. Белл зазначає, що робота з великим обсягом користувацького контенту - це шлях, яким зараз йде журналістика.

Отже, перераховуючи навички онлайнового репортера, ми згадуємо вміння перевіряти інформацію серед інших стандартних навичок. Проте в умовах інформаційної війни саме такі навички стають найзатребуванішими, без них будь-яка пропагандистська діяльність втрачає сенс. Для українських журналістів ці питання стають особливо актуальними в умовах збройної та інформаційної агресії з боку Російської Федерації. Цей північний «сусід» часто не гребує будь-якими брудними методами ведення інформаційної війни задля досягнення своїх геополітичних завдань. Одним з них $є$ поширення недостовірної, спотвореної, брехливої інформації про життя пересічних українців, стан українського війська, економічні та соціальні проблеми тощо. Професійному репортеру для здійснення успішної комунікації з аудиторією потрібно мати на озброєнні цілу низку інструментів та навичок, які дозволяють швидко перевірити інформацію, знайти їі джерела та в разі потреби спростувати. Інколи час, який відведений на ці дії, вимірюється хвилинами. Очевидно, що інформаційну хвилю, створену зумисним вкиданням спотвореного контенту, легше зупинити, поки вона не охопила велику частину аудиторії: вчасно зупинена провокація завдає значно менше шкоди.

Метою запропонованого дослідження є структурування процесу роботи професійного онлайн-журналіста в умовах інформаційних воєн, аналіз наявних методів та інструментів для ефективного аналізу інформації, розробка системи підтримки прийняття рішень щодо подальшого поширення контенту в соціальних медіа, створення низки правил, які дозво- 
ляють мережевому репортеру алгоритмізувати свою діяльність.

Використання запропонованих навичок та інструментів дозволяє вивільнити час журналіста на пошук додаткової інформації або на перевірку вже отриманої за рахунок певної автоматизації процесу верифікації контенту.

\section{2. Методи дослідження}

У статті використовувалися як теоретичні, так і емпіричні методи досліджень.

Зокрема метод збирання інформації та контент-аналіз, які особливо ефективні в соціальних медіа, дозволяють серед різноманіття створюваного користувачами контенту вибирати відповідні приклади та контрприклади для моделювання певної ситуації в роботі онлайн-журналіста. Також використовувався метод спостереження, аналізу та інтерпретації отриманих даних, OSINT-метод. Це дозволило узагальнити та структурувати запропоновані способи верифікації контенту.

Повнотекстовий метод дозволяв знаходити відповідні фрагменти повідомлень у соціальних медіа, порівнювати їх контекст на різних інформаційних платформах. За допомогою методу розпізнавання образів вдається виконати перевірку графічної фото- та відеоінформації та встановити достовірність їі походження.

\section{3. Результати й обговорення}

Наразі величезна кількість інформації міститься в загальному безкоштовному доступі у Всесвітній павутині [14], яка пропонує журналістам необмежений простір для взаємодії в численних соціальних медіа та можливість опрацьовувати останні новини з багатьох джерел водночас. Проте це потребує від репортерів невпинного вдосконалення своїх навичок перевірки фактів у цифровому середовищі. Причому ці факти можуть бути подані у вигляді тексту, зображення, аудіо- та відеозапису. Перевірка складається 3 трьох основних етапів.

I. Моніторинг соціальних медіа в очікуванні певних важливих подій, якщо про них відомо заздалегідь або вони прогнозуються. Також це може бути регулярний моніторинг 3 визначеною періодичністю, що включає в себе заміри аудиторії та контенту, поширюваного в соціальних медіа. Іншими словами, перший етап - це фіксування точки початкового відліку напередодні появи низки топ-новин. Цей "нульовий" момент надалі стане еталоном, з яким будуть порівнюватися зміни стану аудиторії.

II. Після того як очікувані події відбудуться, важливо точно визначити тенденції зміни контенту. Більшість повідомлень мають підлягати цим закономірностям. Будь-яке повідомлення, що виходить за їх межі, має більш детально аналізуватися та перевірятися на достовірність, а також досліджуватись джерела, з яких ця інформація поширювалася. Всі трансформації контенту та аудиторії порівнюються з початковим станом.

III. Згодом на підставі проведеного аналізу робляться висновки щодо достовірності того чи іншого повідомлення та надійності джерела, з якого воно поширювалося.

У межах однієї редакції цю процедуру можна доручити кільком незалежним стороннім експертам, а остаточні висновки робити з урахуванням думки кожного 3 них. Також варто вести статистику точності висновків задіяних експертів. Це дасть змогу в подальшому враховувати їхні думки 3 певним ваговим коефіцієнтом, який характеризує ефективність та надійність висновків. За потреби кожен 3 експертів може залучати на допомогу помічників та будь-який інструментарій. Це можуть бути як онлайн-засоби, так i каталоги бібліотек або архіви паперових ЗМІ. За такою моделлю працює відомий шведський таблоїд "Aftonbladet", сайт якого http:/www.aftonbladet.se/ є найвідвідуванішим у Свропі. Подібну модель варто запроваджувати й в українських 3МI. 
Розглянемо запропоновані етапи детальніше.

\section{1. Моніторинг.}

Підготовку першого етапу потрібно проводити 3 урахуванням крос-медійних технологій [15]. Аналіз різноманітних платформ, на яких поширюється інформація, дозволяє отримати більш достовірні результати та зафіксувати нульовий момент максимально точно. Завдяки цьому отримуємо надійні дані про аудиторію, де поширюється певний контент. Серед платформ передусім слід звернути увагу на соціальні медіа: саме на цих ресурсах відбувається створення контенту безпосередньо користувачами. Найбільші з них за популярністю: Facebook, Twitter, YouTube та різноманітні wiki-ресурси та блоги. Окреме місце серед СМ займають засоби потокового відео, з яких у світі найбільш популярний Bambuser. Цей ресурс вже 8 років доводить свою надійність. Дуже часто, а особливо під час революційних подій в Сгипті та Сирії, він ставав єдиним джерелом об'єктивної інформації. Причому ця інформація була унікальною та нагальною. Ті ж автори, що викладали відео на Bambuser, потім перекладали його і на YouTube. Таким чином журналісти чи експерти мали можливість додати до обраного певне коло стрімерів, яким вони довіряли. Це дозволяло економити час на перевірку матеріалів.

В умовах російської агресії схожу функцію (постачальників достовірної інформації 3 місця бойових дій) брали на себе волонтери або військові ЗСУ та добровольчих батальйонів. Ця інформація була особливо важливою на тлі потужних провокаційних вкидань з боку РФ. На жаль, потокові відео мало використовувалися в зоні АТО, на противагу подіям під час Майдану. Це можна пояснити поганою якістю зв'язку та активною роботою ворожих станцій радіо-електронної боротьби, що порушували стабільність зв’язку. Тому основними соціальними медіа, які ставали в пригоді, були Facebook та Twitter. Останній за рахунок короткого формату своїх повідомлень тривалий час був головним засобом поширення інформації. Згадана погана якість зв'язку зумовила не тільки відсутність онлайн-трансляцій, а й звичайного відео. Тому для поширення графічної інформації лишилися тільки фотографії переважно мобільних телефонів. А це своєю чергою створювало додаткові труднощі для журналіста в перевірці інформації. Очевидно, що фальсифікувати фотографію набагато легше, ніж відеоматеріал.

Інколи не тільки ворожа діяльність Росії, але й некомпетентність волонтерів призводили до появи хвиль спотвореної інформації. Прикладом цього є повідомлення волонтера $з$ критикою фортифікаційної споруди (рис. 1, 2, 3). Загальна аудиторія цього повідомлення сягнула 100 тисяч читачів. 98\% 3 них були негативними в оцінці дій військового керівництва країни. Лише через п'ять годин з'явився пост військового експерта, який пояснив призначення цих оборонних споруд і спростував інформацію волонтера (рис. 4). Це яскравий приклад, коли некомпетентність та поспішність в оцінних судженнях допомагає РФ досягати своєї мети в інформаційній війні з Україною.

Інколи джерелом поширення спотвореної інформації стають самі бійці, що перебувають на лінії зіткнення (рис. 5 та рис. 6). Пояснення їхньої поведінки, яка виникає через постійну напругу та втому, скоріше за все слід шукати в царині психіатрії. Волонтери поширюють подібну інформацію, бо впевнені в надійності їі джерела, а надалі ця хвиля підхоплюється російською пропагандою і її доводиться гасити за допомогою заяв тих самих волонтерів.

Ці приклади підтверджують, що найчастіше джерелом поширення недостовірної брехливої інформації стають українські військовослужбовці та волонтери - безпосередні учасники подій. Інколи через образу на керівництво, інколи через втому або через традиційну недовіру до української влади. Випадків вкидання інформаційного сміття 3 боку РФ набагато менше. Російським пропагандистам доводиться робити з кожним разом більш тонкі провокації, а їх прихильникам дуже рідко вдається створити серйозну 
провокацію, більшість 3 них нескладно розкрити (рис. 7). Це зразок, коли прибічники Росії в Криму намагалися приховати проблеми, які виникли в результаті продуктової блокади 3 боку України у вересні 2015 p.

За таких умов дуже важливо для журналіста не поспішати з поширенням інформації, навіть на шкоду оперативності. Краще витратити зайві хвилини та пошукати підтвердження в інших джерелах або уважно аналізувати ті графічні та відеоматеріали, які потрапляють на очі. Часто ворогам не потрібно створювати власні провокації, достатньо скористатися помилками українських новинарів.

Що довше проводиться моніторинг контенту та аналізуються повідомлення й поведінка експертів, то надійніші рейтинги довіри, які визначаються для кожного джерела повідомлень окремо. Важливо формувати такі рейтинги в межах кожної редакції для службового користування.

\section{2. Перевірка.}

Правильний аналіз даних дозволяє встановити тенденції розвитку тих або інших суспільних явищ, точно спрогнозувати події. Порівнюючи отриману інформацію із заздалегідь підготовленим прогнозом, можна робити попередні висновки щодо іiі достовірності. Це один з дієвих способів перевірки інформації. Фергус Белл [12] вважає, що ключова частина процесу моніторингу полягає у виявленні тенденцій, які можуть бути відслідковані. Це можна робити за допомогою соціальних медіа, зокрема Twitter, Youtube та Facebook.

Зорієнтуватися в актуальній тематиці, яка переважає на певному етапі в соціальних медіа, допомагає такий інструмент, як Trandsmap [16]. У цьому додатку на інтерактивній карті земної кулі вказано, які хештеги та в якій країні $є$ найбільш популярними. За допомогою цього можна дізнатися про тематику новин, які хвилюють аудиторію в тій або іншій місцевості, і відповідно до цих даних готувати матеріали. Це також гарний спосіб перевірки інформації, яка надійшла 3 певної географічної локалізації. Якщо загадані в повідомленні події не представлені на карті Trandsmap, то є додаткові причини не поспішати з їх поширенням і зайвий раз перевірити.

Також популярним способом визначення уподобань читачів лишається анкетування. Для зручності його можна проводити в електронній формі, наприклад, за допомогою системи Polldaddy. Правильно розроблена анкета та проведений аналіз даних дозволяє 3 високим ступенем точності прогнозувати уподобання аудиторії та іï реакцію на той чи інший матеріал або події.

Якщо враховувати, що в умовах інформаційної війни суспільна думка часто формується штучно за рахунок суб'єктивного незбалансованого матеріалу, аналіз аудиторії дозволяє визначити напрямки, куди підштовхують суспільну думку, зрозуміти, до яких висновків ворожі медійники намагаються підвести споживачів інформації. Знаючи це, набагато легше приймати рішення про поширення того чи іншого матеріалу або про підготовку контрматеріалу, який би викривав спотворений або сфальсифікований контент.

Необхідно порівнювати стан аудиторії та склад контенту до та після певних подій 3 висновками надійних, перевірених, незаангажованих експертів. Важливі всі вікові сегменти відвідувачів соціальних медіа, також потрібно аналізувати канали поширення інформації крос-медійних 3МІ. Часто окремі категорії читачів є прихильниками того або іншого каналу поширення інформації - паперової преси, електронних ЗМІ (телебачення, радіо) та мережевих ресурсів. Тому, щоб не звужувати аудиторію досліджень, важливо моніторити всі канали та платформи. Але насамперед слід звертати увагу на такі соціальні медіа, як Facebook, Twitter, Youtube. За даними $[17 ; 18 ; 19 ; 20]$, вони є найбільш популярними у світі станом на 1 липня 2015 року. Загальна щомісячна аудиторія цих 
ресурсів сягає 2 мільйонів користувачів. Необхідно відзначити, що реалізація ідеї семантичної мережі у Всесвітній павутині, запропонована сером Тімом Бернерсом-Лі [14], значно полегшує журналістові пошук інформації.

Важливо критично ставитися до будь-яких стресових новин, які завжди привертають увагу читачів, і шукати їх підтвердження щонайменше у трьох незалежних джерелах. На думку Поля Бредшоу (Paul Bradshow) [10], до будь-якої "смаженої" новини потрібно ставитися 3 позиції, що це занадто добре, щоб бути правдою. Бажано для кожного тематичного блоку новин ставити у відповідність мережу контактів, за допомогою якої ці новини можна було б перевірити. Згадана мережа може будуватися як за професійною, так i за географічною ознакою. Під професійною ми розуміємо підбір експертів, що спеціалізуються з конкретної тематики.

Професійний онлайн-журналіст повинен мати ряд готових рішень для перевірки інформації, щоб в умовах цейтноту швидко визначитися, давати цю новину на сайт чи ні. Інколи прийняти рішення допомагає попередній досвід, отриманий в схожій ситуації, та спеціалізовані веб-ресурси - такі як Flickr, Pinterest тощо. Також корисно використовувати реалізований у популярних пошукових системах, наприклад у Google, механізм пошуку зображення.

Якщо в поширюваному повідомленні йдеться про певну особу, то добре пошукати їі акаунти в різних соціальних медіа та подивитися останні зміни. Таке порівняння може вказувати на спробу змінити інформацію у своєму профілі з метою приховати ті або інші дані. Для пошуку важливо знати адресу електронної скриньки людини. Змінити в профілі пошту набагато складніше, ніж ім'я. Описаний вище метод називається перевіркою соціальної історії [12]. За еволюцією мережевих акаунтів можна перевірити пересування, контакти, зацікавлення певної особи, що поширювала повідомлення. Така інформація допомагає визначити, чи була ця особа очевидцем подій, звідки до неї надійшли новини, сама вона є джерелом інформаційного вкидання чи провокації.

Потрібно не забувати, що, шукаючи певну особу, можна знайти інших $з$ таким самим прізвищем та ім'ям. Тому корисно мати для перевірки ще й мобільний або електронну пошту. Наприклад, у мережі Facebook e-mail дозволяє однозначно визначити акаунт, на відміну від імені користувача. Якщо не вдається перевірити особисті дані користувача, який поширює інформацію в соціальній мережі, доречно звернути увагу на його контакти. Часто російські пропагандисти створювали фальшиві акаунти, від імені яких поширювали інформацію провокаційного характеру в українському сегменті Facebook. На сторінках провокаторів під популярними гаслами боротьби за справедливість поширювалася критика українською влади, зосереджувалася увага на прорахунках в тиловому постачанні українського війська, створювалася атмосфера підозрілості та недовіри до держави Україна. Часто при спробі заблокувати ці акаунти або акаунти їх друзів вони автоматично зникали. Характерною особливістю провокаторів є відсутність побутових фотографій на ïx сторінках. Всі графічні матеріали переважно є інфографікою та мають ілюстративний характер.

Окрему категорію повідомлень становлять пости в соціальних медіа, які з'являються як наслідок ускладнень у стосунках між окремими людьми (рис. 8).

Також крос-медійна перевірка дозволяє викривати фальсифікації. На рис. 9 наведено приклад, як перевірка на відеохостингу Youtube дозволила викрити чергову брудну російську технологію.

Fergus Bell на своїй сторінці у Twitter [12] підкреслював, що під час роботи в Associated Press журналісти ніколи не поширювали без перевірки навіть найгарячішу інформацію 3 Twitter. При перевірці автора твіта слід поцікавитися (якщо він показує деяку інформацію з конкретного місця), чи був він там протягом року, чи контактував в тій місцевості з іншими людьми, які постійно проживають на згаданій території. 
Відома міжнародна волонтерська група InformNapalm.org регулярно публікує результати своїх пошуків у відкритих джерелах [21], використовуючи методологію одного 3 різновидів військової розвідки - OSINT (open source intelligence). Одним 3 прикладів такого розслідування є присутність російських військ на Донбасі (рис. 10). Для цього були професійно досліджені соціальні медіа ВКонтакте та Youtube. Причому досліджувалися не тільки особисті сторінки російського бойовика, але й сторінки його друзів та окремі фотографії з ним з інших ресурсів. Під час розвідки було проаналізовано 38 фотографій, 4 профілі та близько сотні коментарів. У результаті було беззаперечно доведено участь російського кадрового офіцера в конфлікті на Донбасі на боці путінських сепаратистів.

Ще одним важливим напрямком перевірки, який допомагає визначити характер поширюваної інформації, $є$ перевірка за IP-адресою сайту чи автора коментаря. $С$ велика кількість сайтів, зокрема https://www.ripe.net/, які дозволяють за IP-адресою визначити країну поширення інформації. Таким чином можна з'ясувати, приватним було повідомлення чи публікувалося $з$ комп'ютерів певної організації. Складніше проводити перевірку, якщо власник мережевого ресурсу приховує свої IP-адреси за допомогою програмного забезпечення на кшталт Nginx або Deflect. Ще важче, коли за допомогою "спуфінгу" проплачені російські провокатори підмінюють справжню адресу фальшивою. Подібні адреси зазвичай не прив'язані до конкретних організацій і поштових адрес, тому вони одразу викликають підозру. У цьому разі потрібно використовувати інші методи верифікації.

Як згадувалося вище, будь-яку фотографію потрібно перевіряти через Google-пошук зображень або через спеціальні ресурси [22]. Детально ця методика описана в роботі [2] під назвою Reverse Image Search. Дуже часто, щоб виправдати свою агресію проти України, російські пропагандисти використовували фотографії злочинів федеральних військ в Чечні, видаючи їх за події в Україні. Відома фотографія ДТП легковика з БТРом добре розібрана на спеціалізованому ресурсі "StopFake" [23]. На цьому ж сайті підготовлений великий матеріал, де розглядаються багато інших фактів російської брехні про Україну [24].

Спеціальний інформаційний ресурс WolframAlpha дозволяє дізнатися, яка погода була в конкретному заданому місці і в який час [25]. Це дозволяє перевірити відповідність фотографії та погодних умов. На думку Пола Бредшоу [10], завжди потрібно пам'ятати про можливості графічних редакторів, таких як Photoshop. Перед оприлюдненням зображення в Мережі потрібно витрати трохи часу, щоб роздивитися його. Чи однаково падають тіні та світло від усіх об'єктів, чи відповідає одяг погоді або порі року (рис. 7), чи відповідають один одному розпізнавальні знаки на амуніції солдатів та їх озброєнні. При перегляді відео під підозру має потрапляти будь-яка незрозуміла дія оператора. Наприклад, несподівана зміна нахилу камери або формату зображення (з портретного на альбомний чи навпаки), використання кількох різних камер в одному відео. Ці спостереження є підставою вважати, що матеріал редагувався, і більш скептично до нього ставитися. Якщо $є$ можливість, завжди добре обговорити такий матеріал 3 іншими журналістами, які, можливо, вже мали подібний досвід. Одним з найвідоміших прикладів використання графічного редактора (рис. 11) для створення фейку була історія з виступом фальшивого російського експерта на тему збитого малайзійського Боїнга [26].

Завжди необхідно оцінювати, наскільки ризик поширення повідомлення без перевірки менший, ніж ризик втратити час. Інколи репортер перебуває під тиском певних обставин чи зобов'язань і виникає спокуса якнайшвидше розмістити матеріал у Всесвітній павутині. Проте здебільшого це призводить до втрати професіоналізму та репутації. Причому зупинити поширення негативної інформаційної хвилі в соціальних медіа набагато складніше, ніж створити іiі власноруч через професійну помилку. Вже після десятка репостів рівень охоплення аудиторії сягає більше тисячі читачів. Тому і журналістам, $\mathrm{i}$ 
волонтерам, і будь-яким іншим громадським активістам варто витратити кілька годин на перевірку та уточнення фактів, особливо якщо ці факти отримані за допомогою citizenжурналістики.

Бувають обставини, коли репортер не може перевірити конкретну інформацію або через брак ресурсів, або через брак часу, або через професійну складність питання. Тоді на допомогу можуть прийти соціальні медіа, а точніше технологія краудсорсингу [27; 28]. Ця методика полягає в залученні широкої інтернет-аудиторії для пошуку відповіді на конкретне питання. Фактично журналіст поділяє процес розв'язання проблеми на невеликі питання та звертається до мережевої спільноти з пошуком відповіді на них. Такий підхід в перевірці інформації зазвичай виправдовує себе. У результаті онлайн-репортер отримує безкоштовні (на відміну від аутсорсингу [29]) консультації численних учасників соціальних медіа, йому залишається лише проаналізувати відповіді, оцінити наведені аргументи та прийняти рішення. Що ширша множина опитаних користувачів та що більша кількість отриманих коментарів, то вища ймовірність отримання точної інформації. Завжди слід пам'ятати, що існує певна вірогідність отримання помилкового результату, через що доведеться вибачатися перед читачами та нести репутаційні втрати. Низка подібних прикладів описана в роботі [8].

Ще одним яскравим прикладом використання краудсорсингу є залучення великої кількості користувачів для блокування певного акаунту в соціальних медіа за допомогою численних скарг на нього (рис. 12). Це часто використовується в соціальній мережі Twitter. Такі ситуації виникають, коли через профілі окремих користувачів поширюється спотворена інформація з метою вплинути на суспільство або його частину. У Російській Федерації існує спеціальна служба, що розміщується в Санкт-Петербурзі (мікрорайон Ольгино), яка спеціалізується на проведенні інформаційних диверсій у Всесвітній павутині. Одним з ефективних способів боротьби з олгинськими "тролями" є залучення широкого кола читачів соціальної мережі, блогу чи мікроблогу для подачі скарг на відповідні акаунти або блокування їх.

Згадана технологія краудсорсингу притаманна лише новим медіа та неможлива в традиційній журналістиці. Жодне телефонне опитування не здатне забезпечити відповідну аудиторію й вимагає суттєвих витрат часу як з боку редакції, так і з боку респондентів.

\section{3. Поширення інформації.}

У соціальних медіа завжди актуальним залишається питання авторського права. Якщо інформація була отримана від "третіх" осіб, потрібно мати дозвіл на їі використання. Це стосується текстів, фото, відео, аудіоконтенту чи презентацій. Журналіст має контактувати з джерелом інформації, щоб з'ясувати, чи вказувати в даних справжнє ім'я автора або його нікнейм. Якщо немає можливості отримати дозвіл або уточнити інформацію, можна замість контенту розмістити гіперпосилання на нього.

Вказувати джерело походження інформації потрібно абсолютно точно та прозоро, щоб будь-який читач мав змогу перевірити поширюваний контент, наприклад, звернувшись до першоджерела електронною поштою чи іншими каналами комунікації.

Кожен журналіст чи редакція повинні пам'ятати, що, хай там як ретельно перевіряється контент, завжди залишається певна ймовірність помилки, яка призведе до поширення неточної інформації. Крейг Сільверман в [8] підкреслює, що при виправленні помилок у повідомленні потрібно розміщувати спростування в тих самих соціальних медіа, де була розміщена інформація, враховуючи їх специфіку. Важливо пам'ятати: якщо уточнення інформації дати окремим постом у Facebook чи твітом у Twitter, читач може його не помітити. Тому краще виправляти помилки в коментарях до первісного повідомлення - у Facebook, Twitter, Youtube або інших соціальних медіа. Також потрібно дати нове уточнене повідомлення або відредагувати старе, якщо це можливо. Така 
соціальна мережа, як Facebook, зберігає історію редагувань і дає можливість простежити еволюцію того чи іншого поста. Відеохостинг Youtube iсторію не зберігає, а у Twitter станом на жовтень 2015 року взагалі немає можливості редагування твітів. Потрібно прагнути донести відкориговану інформацію до кожного читача, який прочитав первісне повідомлення. Аудиторія повинна побачити та зрозуміти, що це була прикра неточність, а не зумисне спотворення інформації репортером чи редакцією. Такий підхід дасть змогу зберегти журналістську репутацію.

\section{4. Висновки}

Отже, для ефективної перевірки контенту в соціальних медіа потрібно дотримуватися таких правил:

- моніторити всі доступні платформи та канали поширення інформації (Facebook, ВКонтакте, Twitter, Youtube, Bambuser, Soundcloud, Instagram, коментарі до українських онлайн-видань censor.net, pravda.com.ua);

- визначати тенденції та досліджувати аудиторію (Alexa, Tweetdeck, Trendsmap);

- створити мережу експертів за певними темами;

- використовувати онлайн-засоби для аналізу графічної інформації, зображень та відео (Google Images, TinEye, WolframAlfra та ін.);

- використовувати перехресні посилання для підтвердження інформації;

- простежити історію певного повідомлення на різних платформах;

- перевіряти місцепоходження інформації за ІР-адресою;

- перевіряти графічні зображення на відсутність редагування;

- піддавати сумніву всі повідомлення з різким емоційним забарвленням;

- використовувати краудсорсинг;

- не поспішати оприлюднювати інформацію, якщо є час на додаткову перевірку;

- перевіряти право власності на інформацію;

- давати точні посилання на джерела;

- якнайшвидше виправляти помилки, доносити відкориговану інформацію до тієї самої аудиторії.

Можна стверджувати, що з розвитком громадянської журналістики (street journalism) в Україні значно зростає відповідальність журналіста за поширення інформації. Серед безлічі повідомлень потрібно вміти виокремити найточніші та найактуальніші, за короткий час встигнути їх перевірити та поширити на крос-медійних платформах. Такі умови зобов'язують онлайн-репортера володіти сучасними навичками роботи 3 цифровими інструментами для верифікації контенту та мати певну експертну аудиторію, до якої можна звернутися по консультації.

Наявні тенденції розвитку соціальних медіа [23] дозволяють прогнозувати подальше збільшення інтернет-аудиторії i, відповідно, щораз більшу кількість інформації в Мережі. Тому однією з основних навичок веб-журналіста має стати вміння алгоритмізувати процес збору та верифікації контенту.

\section{Подяки}

Автор висловлює щиру подяку DSS380 - школі цифрової безпеки для правозахисників, громадських активістів, представників громадських організацій та ЗМI в Україні при ГО «Інтерньюз Україна» за запрошення на семінари та плідне обговорення викладених вище проблем. 


\section{Ілюстрації}

Pис. 1

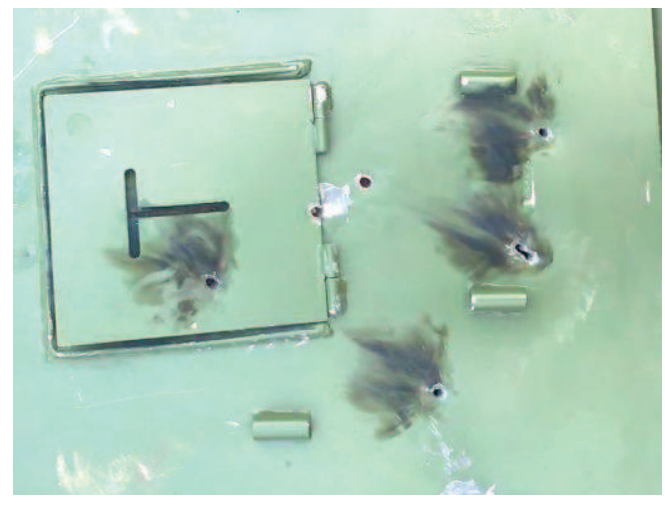

Рис. 3 Текст волонтерки

(пост було видалено з мережі Facebook)

Я не фахівець, звичайно, в цій справі - тільки вчусь. тому, як щосьь не то виправляйте мене. Ца штука встановлюється на лініи оборони і вважаеться "вогнева точка". Така собі фортифікациина споруда, ніби бункер звідки бійці өідстрілюються по наступаючому ворогу. По ідеі вона броньована, імала би бути добре броньована, тому що призначена для захисту під час бойових дій... ЦҺю штуку надало Міноборони, за інсайдерськоюю інфою коштує - 44 тиссячі привень одна. А тепер саме головніше, бійці 128 бригади протестували ї, стріляли з Пк 762 та АК 74 - як бачите кулепробивне. Уваға питання - для чого витрачати державні кошти для купівлі речей, які не гарантують безпеку пюдям? Віямивання бабла чи як це паскудство називається?

I. Подобаеться К Коментувати $\nRightarrow$ Поширити
Рис. 2

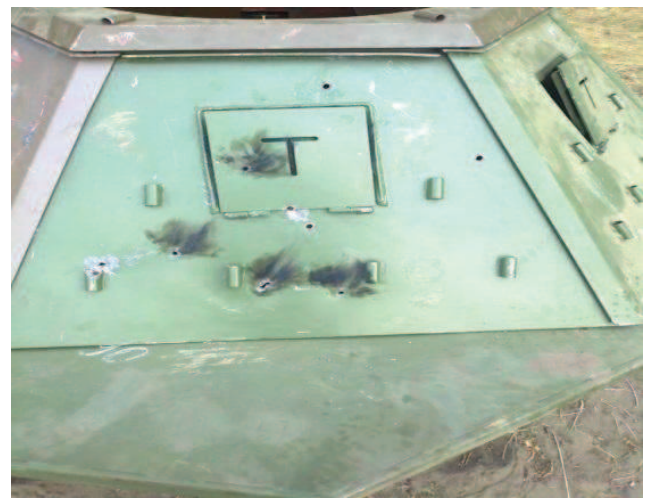

Рис. 4. Відповідь експерта

(https://www.facebook.com/photo.php?fbid=1091 436930867709\&set=a.314896515188425.88344.1

$00000042388077 \&$ type $=1 \&$ theater $)$.

Я знаю, что многие банят, расфрендживают и всячески не любят слова зрада. Но это не в целях позлорадствовать - просто истина дороже, а какое ещце емкое слово придумать для тотального негатива, которым пропитаны социалки каждый день? В общцем, это малое огневое сооружение. Держит осколки от ВОГ, некрупные минометные, стрелково оружие с дистанции 120-150 метров, рикошеты, МОН, есть видео с испытаний, как 3 У-2312 на дистанции не приводит к пробитиям. На фото колпак шили почти в упор, а подпалины говорят нам, что это боеприпас Б3 - пуля горела в толще (если можно так назвать по сабжу) брони. Девушка волонтер говорит нам в своем посте, что так никуда не годится. Но в таких условиях пуля 7.62 Б3 пробивает БТР, никуда не денется. Ибо физика, сопротивление материалов и темный гений Империи Зла. Более тoro. уже есть боеприпас в 5.45, пробивающий на сто метров 16 мм стальной плиты. Такие дела. Но МВС нужна не для того, чтобы её шить в упор, а потом клеймить злочинну владу. Нит. Её окапьвают, подводят снизу траншею. укрепляют мешками, а после из бойницы ведут огонь пулеметом. Даже старичок РПК на 500 метров может устроить атакующим

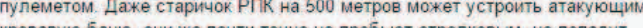
кровавую баню, они же почти точно не пробьют стрелковым, не попадут

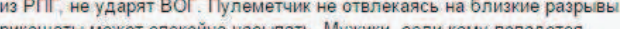
рикошеты может спокойо насьпать. Мужики если кому попадется бронеколпак - не гасите по нему в упор. Копайте и усиливайте. Пот сохраняет кровь. А эта штука не даст подавить пулемет осколочным оружием или попасть по пулеметчику легким стрелковьм. А "Утес" ещце потаскай по полю под огнем и залепи в небольшой срез башни над окопом. 44 тысячи гривен - это 2000 долларов, не ждите от них чуда. Но это лучше чем два ковша на бригаду и БСЛ как прошлым летом. Конструкцию довольно просто устанавливать и менать позицию, она стойка к опрокидыванию, малозаметна на фоне зеленки, её можно даже не встраивать в блиндаж, а просто оставлять как огневую точку в траншее. Как по мне - стоит свои 2000 долларов. 


\section{Рис. 5. Заява керівництва 93-ї бригади 3СУ}

(https://www.facebook.com/permalink.php?story fbid $=402191166644346 \&$ id $=373736899489773$ )

6 93-я ОМБр додае 6 нових світлин

6 вересня 02207 -

ПОВІДОМЛЕННЯ ПРЕС-СЛУЖБИ 93-ї ОМБр

У зв'язку з появою неперевіреної інсормації про знищення противником українського блокпосту поблизу селищца Опитне та загибель внаслідок обстрілу великої кількості бійців, яка набула широкого розголосу і фактично вилилася в інформаційну диверсію прес-служба 93-і ОМБр повідомляє наступне.

В зоні відповідальності 93-і бригади ЗСУ жоден з підрозділів батальйону "Айдар" службу не несе. Натомість один з підрозділів бригади справді частково укомплектований колишніми "айдарівцями", які влилися до складу нашог частини на індивідуальних засадах. Минула ніч, як і декілька попередніх, на північно-західних околицях Донецька, зокрема в районі с. Опитне відзначилася відносним затишшям. Прицільного вогню по українських позиціях противник не

Блокпост поблизу Опитного під обстріли не потрапляв. Усі бійці. які несуть службу на цій позиціі, живі та здорові і шлють гарячий привіт Своїм рідним і близьким ::)

Нижче дивіться спростування від авторки посту, 3 якого все почалося, а також фото бійців з блокпосту, який "знищила" чиясь хвора фантазія

\section{Рис. 6. Пояснення волонтерки}

(https://www.facebook.com/permalink.php?story fbid $=881459651908868 \&$ id $=100001345231738$ )
Pис. 7

(http://joyreactor.cc/post/2198298)

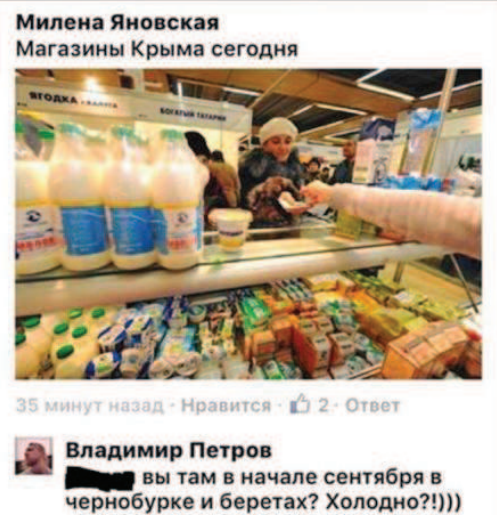

Рис. 8

(https://www.facebook.com/tpguba/posts/7166711

$78476932)$

19.09 .2015

Поступили травмированные и больные Солнышки

Травмы бывают разные : спрыгнул неудачно с брони и тд

аватарские Болезни также - на фоне стресса гипертония, хроника

просыпается или аватарские -обострение гастрита. панкреатита на

роне спиртного в огромнейших количествах

И страдают нормальные от соседства с аватарами

Только профессиональная армия устранит массу проблем Вчера девушка звонит

-помогите, мой друг с пулевым ранением, пришел в себя в

реанимации на передке. нужна помоць

Странно, однако, с ранениями в двух секторах, знаю точно, не

поступали. Нахожу друга- удалили аппендицит, гуляет по территории видать на жалость хотел надавить

Перезвонила, что с ним все нормально, чтобы не переживала.

Сталкиваюсь с "ффантазиями" частенько, а у людей вопросы -почему информация не совпадает с инсо пресслужбы АТО по раненым и. погибшим ? А вот у меня совпадает.

Так что знайте, что не всему н в соцсетях, $к$ сожалению, можно верить

Доверяй, но проверяй 
Рис. 9

(пост було видалено з мережі Facebook)

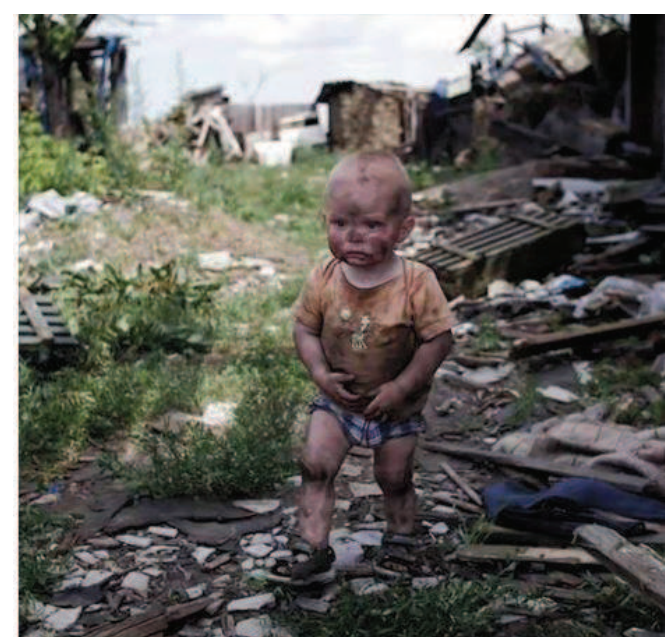

Рустем Адагамов

22 вересня 0 21:14 - Prague, Czech Republic - 3мінено - a)

Это фото сейчас усиленно форсят в вконтактике и одноквасникам с подлисью. что это "ребенокиз Донбасса после бомбежки разыскивает свою погибшуро мать". На самом деле этого малыша намазали сажей и пустили гулять по

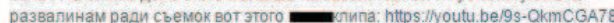

\section{Рис. 11}

(http://www.unian.ua/politics/1009743-rosiyskiblogeri-sprostuvali-shaleniy-feyk-kremlya-probojing-yakiy-bulo-zbito-vinischuvachem.html)

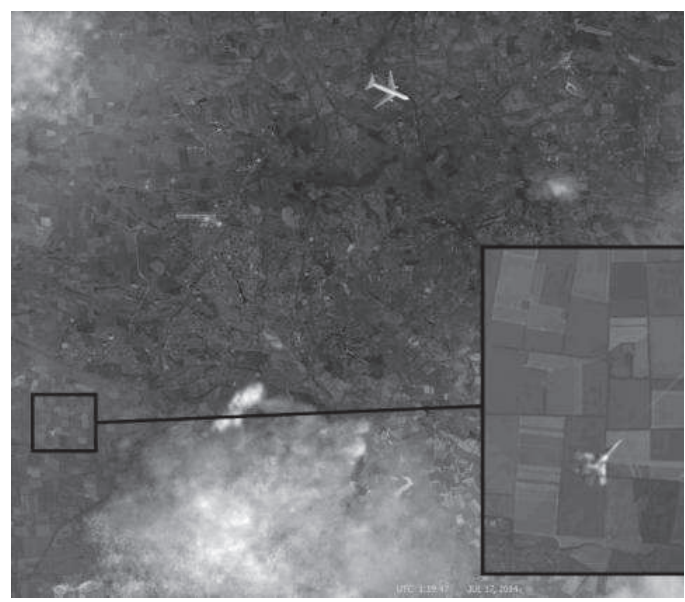

Рис. 10

(https://ua.informnapalm.org/nachalnyk-vijskppo-6-yi-armiyi-rf-voyuye-na-donbasi/)

"Начальник військ ППО 6-ї армії РФ" воює на Донбасі

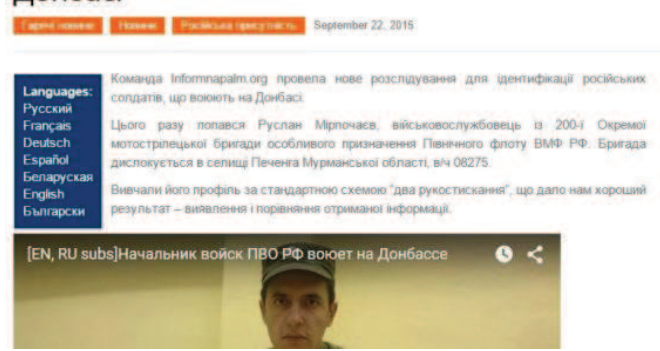

Рис. 12

(https://twitter.com/kodeksunet/status/648587014 342881281)

2. 9. януковича HET!

\% +2 Читати

Дружно БАНИМ этого

\#vata_v_ban

twitter.com/O_V_Klymenko

Pina

Рinaty Александр КЛИМЕНкО 


\section{References}

1. O'Reilly, T. (2005), "What Is Web 2.0", available at: http://www.oreilly.com/pub/a/web2/archive/what-is-web-20.html (accessed December 23, 2015).

2. Ryabichev, V.L. (2014), "Model of network journalist", Institute of Journalism Proceedings [Naukovi Zapysky Instytutu Zhurnalistyky], vol. 57, pp. 189-193. (in Ukrainian).

3. Bartlett, R. (2012), "\#jpod - Advice on verifying social media content and correcting errors", available at: https://www.journalism.co.uk/podcast/-jpod--advice-on-verifying-socialmedia-content-and-correcting-errors/s399/a555081 (accessed December 23, 2015).

4. Bartlett, R. (2013), "\#Tip of the day for journalists: Verifying Twitter content", available at: https://www.journalism.co.uk/tip-of-the-day/-tip-of-the-day-for-journalists-verifying-twittercontent/s419/a561944/ (accessed December 23, 2015).

5. Bartlett, R. (2011) "\#Tip of the day from Journalism.co.uk - connecting via social media", available at: https://www.journalism.co.uk/tip-of-the-day/-tip-of-the-day-from-journalism-co-uk-connecting-via-social-media/s419/a561571 (accessed December 23, 2015).

6. Pocheptsov, H. (2015), Modern Information War [Suchasni informatsiyni viyny], Publishing house "Kyiv-Mohyla Academy", Kyiv, 498 p. (in Ukrainian).

7. Arquilla, J. \& Ronfeldt, D. (2005), Networks and Netwars [Merezhi i merezhni viyny], Publishing house "Kyiv-Mohyla Academy", Kyiv, 350 p. (in Ukrainian).

8. Silverman, C. (2014), Verification Handbook, The Poynter Institute, St. Petersburg (Florida), 122 p., available at: http://goo.gl/fZMGRY (accessed December 23, 2015).

9. Silverman, C. and Jarvis J. (2009) Regret the Error: How Media Mistakes Pollute the Press and Imperil Free Speech New York, Union Square Press, Somerville, 368 p.

10. Bradshaw, P. (2015), "Twitter", available at: https://twitter.com/paulbradshaw (accessed December 23, 2015).

11. Bradshaw, P. (2013), Scraping for Journalists, Leanpub, Victoria (British Columbia), 502 p., available at: http://acervo-digital.espm.br/e-books/scrapingforjournalists.pdf (accessed December 23, 2015).

12. Bell, F. (2015), "Twitter", available at: https://twitter.com/fergb?lang=uk (accessed December 23, 2015).

13. Bell, F. (2013), "How to work successfully with user generated content as a journalist", available at: http://sverigesradio.se/sida/artikel.aspx?programid=4042\&artikel $=5548834$ (accessed December 23, 2015).

14. Berners-Lee, T. (2000), Weaving the Web: The Original Design and Ultimate Destiny of the World Wide Web by Its Inventor, HarperCollinsPublishers, New York, 246 p.

15. Ryabichev, V.L. (2013) "The multiplatform conception in the modern journalism", Institute of Journalism Proceedings [Naukovi Zapysky Instytutu Zhurnalistyky], vol. 52, pp. 98-101. (in Ukrainian).

16. Trendsmap (2015), "Trendsmap", available at: http://trendsmap.com/ (accessed December 23, 2015).

17. Sareah, F. (2015), "Interesting Statistics for the Top 10 Social Media Sites", available at: http://smallbiztrends.com/2015/07/social-media-sites-statistics.html (accessed December 23, 2015).

18. The eBusiness Guide (2015), "Top 15 Most Popular Social Networking Sites. October 2015", available at: http://www.ebizmba.com/articles/social-networking-websites (accessed December 23, 2015).

19. Moreau, E. (2015), "Top 15 Social Networking Sites You Should Be Using 2015", available at: http://webtrends.about.com/od/socialnetworkingreviews/tp/Social-Networking-Sites.htm (accessed December 23, 2015).

20. Ryabichev, V.L., Karanov, Y.O. \& Maystruk, Y.A. (2013), "The development of the 
Ukrainian social media in 2010-2012", Institute of Journalism Proceedings [Naukovi Zapysky Instytutu Zhurnalistyky], vol.51, pp. 157-160. (in Ukrainian).

21. Inform Napalm (2015), "InformNapalm", available at: https://ua.informnapalm.org/ (accessed December 23, 2015).

22. TinEye (2015), "TinEye Reverse Image Search", available at: http://www.tineye.com/ (accessed December 23, 2015).

23. Ryabichev, V.L., Artyushchyk, A.O. \& Ryabicheva, O.V. (2015), "The directions of the progress of the social media in Ukraine in 2014", Institute of Journalism Proceedings [Naukovi Zapysky Instytutu Zhurnalistyky], vol. 58, pp.153-159. (in Ukrainian)

24. StopFake.org (2014), "Lies: Near Kramatorsk Tank Crushes a Car with People", available at: http://www.stopfake.org/en/russia-s-top-lies-about-ukraine-part-4/ (accessed December 23, 2015).

25. WolframAlpha (2015), "Alpha: Computational Knowledge Engine", available at: http://www.wolframalpha.com/examples/WeatherAndMeteorology.html (accessed December 23, 2015).

26. Information agency UNIAN (2014), "Russian bloggers disproved Kremlin's mad fake about the Boeing allegedly shot down by the Ukrainian fighter", available at: http://www.unian.net/politics/1009740-rossiyskie-blogeryi-oprovergli-bezumnyiy-feyk-kremlyapro-sbityiy-istrebitelem-boing.html (accessed December 23, 2015). (in Russian).

27. Howe, J. (2006), "The Rise of Crowdsourcing", Wired, issue 14.06, available at: http://www.wired.com/2006/06/crowds (accessed December 23, 2015).

28. Howe, J. (2012), Crowdsourcing: Why the Power of the Crowd is Driving the Future of Business, Alpina Pablisher, Moscow, 288 p. (in Russian).

29. Bravard, J.L. \& Morgan R. (2007), Smarter Outsourcing: An Executive Guide to Understanding, Planning and Exploiting Successful Outsourcing Relationships, Balance Business Books, Moscow, 475 p. (in Russian).

\section{Список джерел}

1. O'Reilly T. What Is Web 2.0 [Електронний ресурc] // O'Reilly Media. - Режим доступу: http://www.oreilly.com/pub/a/web2/archive/what-is-web-20.html. - Назва 3 екрану. - Дата доступу: 23.12.2015.

2. Рябічев В.Л. Модель мережевого журналіста / В.Л. Рябічев //Наукові записки Інституту журналістики : наук. журн. [гол. ред. В.В. Різун]. - Т. 57. - К.: КНУ, 2014. - С.189193.

3. Bartlett R. \#jpod - Advice on verifying social media content and correcting errors [Електронний ресурс] // Journalism jobs (media, editorial), news for journalists - Режим доступу: https://www.journalism.co.uk/podcast/-jpod--advice-on-verifying-social-mediacontent-and-correcting-errors/s399/a555081/. - Назва з екрану. - Дата доступу: 23.12.2015.

4. Bartlett R. \#Tip of the day for journalists: Verifying Twitter content [Електронний pecypc] // Journalism jobs (media, editorial), news for journalists - Режим доступу: https://www.journalism.co.uk/tip-of-the-day/-tip-of-the-day-for-journalists-verifying-twittercontent/s419/a561944/. - Назва з екрану. - Дата доступу: 23.12.2015.

5. Bartlett R. \#Tip of the day from Journalism.co.uk - connecting via social media [Електронний ресурс] // Journalism jobs (media, editorial), news for journalists - Режим доступу: https://www.journalism.co.uk/tip-of-the-day/-tip-of-the-day-from-journalism-co-uk-connecting-via-social-media/s419/a561571/. - Назва з екрану. - Дата доступу: 23.12.2015.

6. Почепцов Г. Сучасні інформаційні війни: науково-популярне видання. /Г. Почепцов. - К.: Видавничий дім "Києво-могилянська академія", 2015 - 498 с. 
7. Арквілла Дж. Мережі і мережні війни: наукове видання. / Дж. Арквілла, Д. Ронфельдт. - К.: Видавничий дім "Києво-Могилянська академія", 2005. - 350 с.

8. Сілверман К. Посібник з веріфікації [Електронний ресурс] // Електронна бібліотека Інституту журналістики. http://journlib.univ.kiev.ua/Books/Verification_handbook_UA.pdf. - Назва з екрану. - Дата доступу: 23.12.2015.

9. Silverman C. Regret the Error: How Media Mistakes Pollute the Press and Imperil Free Speech New York. / Craig Silverman, Jeff Jarvis. - Somerville: Union Square Press, 2009 - 368 pp.

10. Bradshaw P. [Електронний ресурс] // Twitter. - Режим доступу: https://twitter.com/paulbradshaw. - Назва з екрану. - Дата доступу: 23.12.2015.

11. Bradshaw P. Scraping for Journalists [Електронний ресурс] // Scraping for journalists Режим доступу: http://acervo-digital.espm.br/e-books/scrapingforjournalists.pdf. - Назва 3 екрану. - Дата доступу: 23.12.2015.

12. Bell F. [Електронний pecypc] // Twitter. - Режим доступу: https://twitter.com/fergb?lang=uk. - Назва з екрану. - Дата доступу: 23.12.2015.

13. Bell F. How to work successfully with user generated content as a journalist [Електронний pecypc] // SverigesRadio. - Режим доступу: http://sverigesradio.se/sida/artikel.aspx?programid=4042\&artikel=5548834. - Назва з екрану. Дата доступу: 23.12.2015.

14. Berners-Lee T. Weaving the Web: The Original Design and Ultimate Destiny of the World Wide Web by Its Inventor / Tim Berners-Lee. - New York: HarperCollinsPublishers, 2000. - $246 \mathrm{p}$.

15. Рябічев В.Л. Мультиплатформна концепція в сучасній журналістиці / В.Л. Рябічев //Наукові записки Інституту журналістики: наук. журн. [гол. ред. В.В. Різун]. - Т. 52. - К.: КНУ, 2013. - C.98-101.

16. Trendsmap [Електронний pecypc] //Trendsmap. - Режим доступу: http://trendsmap.com/. - Назва з екрану. - Дата доступу: 23.12.2015.

17. Sareah F. Interesting Statistics for the Top 10 Social Media Sites [Електронний ресурс] // Small Business Trend. - Режим доступу: http://smallbiztrends.com/2015/07/social-mediasites-statistics.html. - Назва з екрану. - Дата доступу: 23.12.2015.

18. Top 15 Most Popular Social Networking Sites. October 2015 [Електронний ресурс] // The eBusiness Guide - Режим доступу: http:/www.ebizmba.com/articles/social-networkingwebsites. - Назва з екрану. - Дата доступу: 23.12.2015.

19. Moreau E. Top 15 Social Networking Sites You Should Be Using 2015 [Електронний pecypc] // Web Trends: What Are People Talking About Online? - Режим доступу: http://webtrends.about.com/od/socialnetworkingreviews/tp/Social-Networking-Sites.htm. - Haзва з екрану. - Дата доступу: 23.12.2015.

20. Рябічев В.Л. Розвиток соціальних медіа в Україні протягом 2010-2012 рр. / В.Л. Рябічев, С.О. Каранов, Я.А. Майструк //Наукові записки Інституту журналістики: наук. журн. [гол. ред. В.В. Різун]. - Т.51. - К.: КНУ, 2013. - С.157-160.

21. Inform Napalm [Електронний ресурс] // InformNapalm - Режим доступу: https://ua.informnapalm.org/. - Назва з екрану. - Дата доступу: 23.12.2015.

22. TinEye [Електронний ресурс] // TinEye Reverse Image Search - Режим доступу: http://www.tineye.com/. - Назва з екрану. - Дата доступу: 23.12.2015.

23. Рябічев В.Л. Тенденції розвитку соціальних медіа в Україні в 2014 році / В.Л. Рябічев, А.О. Артющик, О.В. Рябічева //Наукові записки Інституту журналістики: наук. журн. [гол. ред. В.В. Різун]. - Т.58. - К.: КНУ, 2015. - С.153-159.

24. StopFake.org Lies: Near Kramatorsk Tank Crushes a Car with People [Електронний pecypc] // StopFake - Struggle against fake information about events in Ukraine. - Режим дос- 
тупу: http://www.stopfake.org/en/russia-s-top-lies-about-ukraine-part-4/. - Назва 3 екрану. Дата доступу: 23.12.2015.

25. WolframAlpha [Електронний ресурс] // Alpha: Computational Knowledge Engine. Режим доступу: http://www.wolframalpha.com/examples/WeatherAndMeteorology.html. Назва з екрану. - Дата доступу: 23.12.2015.

26. Российские блогеры опровергли безумный фейк Кремля про сбитый истребителем "Боинг" [Електронний ресурс] // Новини УНІАН. - Режим доступу: http://www.unian.net/politics/1009740-rossiyskie-blogeryi-oprovergli-bezumnyiy-feyk-kremlyapro-sbityiy-istrebitelem-boing.html. - Назва з екрану. - Дата доступу: 23.12.2015.

27. Jeff Howe The Rise of Crowdsourcing [Електронний pecypc] // Wired. - 2006. - Issue 14.06. - Режим доступу: http://www.wired.com/2006/06/crowds/.- Назва з екрану. - Дата доступу: 23.12.2015.

28. Хау Дж. Краудсорсинг: Коллективный разум как инструмент развития бизнеса (Crowdsourcing: Why the Power of the Crowd is Driving the Future of Business) / Джефф Хаy - М.: «Альпина Паблишер», 2012. - 288 с.

29. Бравар Ж.-Л. Эффективный аутсорсинг. Понимание, планирование и использование успешных аутсорсинговых отношений / Ж.-Л. Бравар, Р. Морган. - М.: Баланс Бизнес Букс, 2007. -475 c. 